\title{
BERFIKIR KRITIS DALAM PENGAMBILAN KEPUTUSAN PADA ASUHAN KEPERAWATAN
}

JIHAN ASYLA

Email : jihanasyla20@gmail.com

\begin{abstract}
ABSTRAK
Latar Belakang : Berpikir kritis memiliki kaitan dalam proses pengambilan keputusan dan penilaian klinis yang akan menjadi penentu pemberian asuhan keperawatan yang berkualitas. Oleh karena itu, seorang Perawat wajib berpikir secara kritis dalam praktik keperawatannya. Tujuan : untuk mengetahui hubungan berpikir kritis dalam proses pengambilan keputusan, sehingga nantinya berguna bagi perawat karena dengan mudah untuk mengambil keputusan dalam menetapkan suatu kondisi yang dialami oleh pasien. Metode : Rancangan penelitian yang

Pembahasan : Berpikir kritis dalam keperawatan merupakan komponen yang sangat penting karena sebagai salah satu penentu kualitas asuhan keperawatan yang diberikan serta untuk menguji berbagai alasan secara rasional sebelum mengambil keputusan dalam asuhan keperawatan, sehingga apa yang didapatkan ataupun diberikan akan maksimal dan jauh lebih baik. Kesimpulan : Untuk mengabil suatu keputusan pun perawat tidak boleh asalasalan harus memperhatikan banyak hal yang nantinya akan menjadi keputusan yang akurat dan jelas.
\end{abstract} digunakan adalah literature review. Dengan melakukan analisis dan kajian bebas pada jurnal, e-book, maupun buku teks yang berkaitan dengan materi pembelajaran yaitu bepikir kritis dimana berpikir kritis memiliki kaitan dalam proses pengambilan keputusan. Hasil : Pada literature review didapatkan hasil bahwa untuk meningkatkan cara berpikir kritis perawat dilakukan dengan menganalisis, mengkaji, mengeksplorasi berbagai bentuk bacaan demi meningkatnya sikap berpikir kritis.
Kata Kunci : Perawat, Berpikir kritis, proses pengambilan keputusan.

\section{LATAR BELAKANG}

Berfikir kritis dalam pengambilan keputusan sangatlah penting, terutama pada asuhan keperawatan sangat dibutuhkan tindakan yg cepat dan tepat dalam pengambilan keputusan. Oleh karena itu Perawat sebagai pemberi asuhan selalu dituntut untuk selalu memberikan 
tindakan yang cepat dan tepat. Keadaan tersebut menjadikan perawat untuk selalu berpikir kritis dalam mengambil keputusan dalam setiap tindakan nya. Maka dari itu diperlukan dasar - dasar yang tepat bagi perawat untuk berpikir kritis dan mengambil keputusan dengan cepat dalam setiap memberikan tindakan kepada pasien.

Perawat memiliki peranan penting dalam mengambil keputusan klinis yang tepat dan akurat karena perawat akan menemukan berbagai situasi klinis yang berkaitan dengan masyarakat atau pasien,anggota keluarga, dan tenaga kesehatan lainnya, sehingga sangat penting untuk berpikir kritis pada setiap situasi.

Jika dalam proses pengambilan keputusan dilakukan secara tergesa-gesa ataupun tidak tepat, ini akan berpengaruh bagi kualitas serta kuantitas pelayanan kesehatan kepada pasien. Berpikir kritis dapat dijadikan sebuah acuan bagi pelayanan yang akan diberikan pasien agar lebih cepat dan tepat dalam proses pengambilan keputusan.

Berpikir kritis sangat berkaitan dalam proses pengambilan keputusan maupun pemberian asuhan keperawatan yang professional. Perawat diminta untuk bisa berpikir kritis dengan menggunakan pengetahuan mengenai ilmu keperawatannya secara menyeluruh agar bisa memberikan perawatan yang efektif
Berfikir kritis dalam pengambilan keputusan secara luas dipandang sebagai kompetensi dasar bagi perawat untuk kemampuan

menginterpretasi,menganalisis, dan mengevaluasi dalam melakukan tindakan keperawatan dan dapat memberikan perawatan yang lebih baik .Berpikir kritis dalam keperawatan merupakan komponen dasar dalam mempertanggung jawabkan profesi dan kualitas perawatan.

kritis memiliki kaitan dalam proses pengambilan keputusan dan penilaian klinis yang akan menjadi penentu pemberian asuhan keperawatan yang berkualitas. Oleh karena itu, seorang Perawat wajib berpikir secara kritis dalam praktik keperawatannya. Yaitu bertujuan untuk mengetahui hubungan berpikir kritis dalam proses pengambilan keputusan, sehingga nantinya berguna bagi perawat karena dengan mudah untuk mengambil keputusan dalam menetapkan suatu kondisi yang dialami oleh pasien secara cepat dan tepat.

Kesimpulannya adalah perawat yang berfikir kritis berpeluang besar untuk mampu melakukan tindakan keperawatan maupun asuhan keperawatan dengan baik jika dibandingkan dengan perawat yang kurang berpikir kritis dalam pengambilan keputusan melakukan tindakan dan asuhan keperawatan. 
METODE : Rancangan penelitian yang digunakan adalah literature review. Dengan melakukan analisis dan kajian bebas pada jurnal, e-book, maupun buku teks yang berkaitan dengan materi pembelajaran yaitu bepikir kritis dimana berpikir kritis memiliki kaitan dalam proses pengambilan keputusan.

Artikel ataupun jurnal yang digunakan pada literature review ini adalah artikel atau jurnal yang didapatkam dari google scholar, google book, library usu pada 10 tahun terakhir penerbitan. Dalam mencari literature reviewnya, menggunakan kata kunci berpikir kritis, pengambilan keputusan keperawatan dan perawat.

Rancangan penelitian ini juga menggunakan metode referensi melalui jurnal-jurnal yang terkait dengan pengambilan keputusan perawat dengan menggunakan metode Critical Thinking dengan kritis, efektif dan sistematis.
HASIL: Pada literature review didapatkan hasil bahwa untuk meningkatkan cara berpikir kritis perawat dilakukan dengan menganalisis, mengkaji, mengeksplorasi berbagai bentuk bacaan demi meningkatnya sikap berpikir kritis. Pembahasan : Berpikir kritis dalam keperawatan merupakan komponen yang sangat penting karena sebagai salah satu penentu kualitas asuhan keperawatan yang diberikan serta untuk menguji berbagai alasan secara rasional sebelum mengambil keputusan dalam asuhan keperawatan, sehingga apa yang didapatkan ataupun diberikan akan maksimal dan jauh lebih baik. Kesimpulan : Untuk mengabil suatu keputusan pun perawat tidak boleh asal-asalan harus memperhatikan banyak hal yang nantinya akan menjadi keputusan yang akurat dan jelas. 


\section{PEMBAHASAN}

Konsep Berpikir Kritis pada Pengambilan keputusan dalam asuhan Keperawatan

Keputusan dalam Berpikir Kritis adalah suatu istilah yang digunakan untuk menjelaskan suatu proses kognitif yang mengarahkan pemecahan masalah dan pengambilan keputusan, dimana merupakan proses perbaikan dari pikiran yang mengubah metode proses berpikir untuk meyakinkan bahwa kesimpulan yang diambil telah tepat, beralasan dan teliti (Black \& Hawk, 2009).

suatu masalah yang efektif caranya adalah dengan menanamkkan kemampuan berpikir kkritis.

D Berpikir Kritis dalam Pengambilan Keputusan

Kemampuan berpikir kritis dapat ditingkatkan dengan motivasi yang positif dari lingkungan tempat perawat bekerja.
Suatu kreativitas penting untuk membangkitkan motivasi secara individu, sehinnga seorang peraeat mampu mengembangkan konsep baru dengan pendekatan inovatif dalam memecahkan masalah agar keputusan yang diambil akurat dan jelas. Perawat juga harus terbuka dalam menerima kritik karena akan mengakibatkan hal yang positif.

\section{Proses Pengambilan} Keputusan

Proses pengambilan keputusan adalah salah satu penyelesaian yang dinamis. Penyebab umum gagalnya pengambilan keputusan adalah kurang tepat dalam mengidentifikasi masalah . Oleh karena itu, identifikasi masalah merupakan langkah yang paling penting karena kualitas hasil tergantung pada keakuratan hasil dalam mengidentifikasi masalah.Berpikir kritis sangatlah penting karena sebagai salah satu penentu kualitas asuhan keperawatan yang diberikan serta untuk menguji berbagai alasan secara rasional sebelum mengambil 
keputusan dalam asuhan keperawatan, sehingga apa yang didapatkan ataupun diberikan akan maksimal dan jauh lebih baik.

Pengambilan keputusan adalah kemampuan mendasar bagi praktisi kesehatan, khususnya dalam asuhan keperawatan dan kebidanan.tidak hanya berpengaruh pada pada proses pengelolaan asuhan keperawatan saja, tetapi penting untuk merancang suatu perubahan. Seorang perawat harus mempunyai kemampuan menyelesaikan suatu masalah yang efektif caranya adalah dengan menanamkkan kemampuan berpikir kkritis.

Pengambilan keputusan adalah suatu pendekatan yang sistematis terhadap hakekat suatu masalah dngan mengumpulkan fakta-fakta dan data, menemukan alternative yang matang untuk mengambil suatu tindakan yang tepat. Ada lima hal yang perlu diperhatikan dalam pengambilan keputusan, yaitu : 1) Dalam proses pengambilan keputusan tidak terjadi secara kebetulan; 2) Masalah harus diketahui dengan jelas; 3)
Pengambilan keputusan tidak dilakukan secara sembrono; 4) Pemecahan masalah harus didasarkan pada fakta-fakta yang telah terkumpul secara sistematis; 5) Keputusan yang baik adalah keputusan yang telah dianalisa secara matang.

Apabila pengambilan keputusan tidak didasarkan pada kelima hal diatas, akan menimbulkan berbagai macam masalah diantaranya :

1. Tidak tepatnya keputusan

2. Tidak terlaksananya keputusan karena tidak sesuai dengan kemampuan organisasi baik dari segi manusia, uang maupun material

3. Ketidakmampuan pelaksana untuk bekerja karena tidak ada sinkronisasi antara kepentingan organisasi dengan orang-orang di dalam organisasi tersebut.

4. Timbulnya penolakan terhadap keputusan.

Faktor-faktor dalam Pengambilan Keputusan 
Banyakfaktor yang berpengaruh kepada indivvidu mauupun kelompok dalam mengambil keputusan, yaitu:

\section{Faktor internal}

Faktor internal dari diri perawat sangat mempengaruhu proses pengambilan keputusan . Faktor internal tersebut meliputi keadaan emosional dan fisik, personal karakteristik,sosial, budaya, latar belakang filosofi, masa lalu, dan sikap pengambilan keputusan yang dimiliki.

\section{Faktor eksternal}

Faktor eksternal termasuk kondisi dan lingkungan waktu. Suatu nilai yang berpengaruh pada semua aspek dalam pengambilan keputusan adalah pernyataan masalah, bagaimana evaluasi itu dapat dilaksanakan.dengan baik.

Menurut Bandman (1998) berfikir kritis adalah pengujian yang rasional terhadap ide- ide, pengaruh, asumsi, prinsip-prinsip, argument, kesimpulan-kesimpulan, isu-isu, pertanyaan, keyakinan dan
aktivitas.Pengujian ini berdasarkan alasan ilmiah, pengambilan keputusan, dan kreativitas.

Berfikir kritis tidak hanya memerlukan kemampuan kognitif, tetapi juga kebiasaan seseorang untuk bertanya, mempunyai hubungan yang baik, jujur dan selalu mau untuk berfikir jernih tentang suatu masalah (Facione,1990). Jika diterapkan pada keperawatan, maka inti dari berpikir kritis menunjukkan proses pengambilan keputusan klinis yang kompleks. Perawat yang menerapkan pemikiran kritis dalam bekerja akan focus terhadap penyelesaian masalah

dan membuat keputusan, serta tidak akan membuat keputusan yang terburu-buru ataupun ceroboh (Kataoka-Yahiro dan Saylor, 1994). Perawat yang bekerja dalam situasi kritis seperti di unit gawat darurat sering bertindak terlalu cepat pada saat ada masalah. Namun, perawat tersebut telah berlatih disiplin dalam membuat suatu keputusan untuk menghindari keputusan yang terlalu cepat dan tidak tepat. Ada juga beberapa karakteristik berpikir kritis yaitu :

$\square$ Konseptualisasi 
Konseptualisasi artinya proses intelektual membentuk suatu konsep.

\section{Rasional dan Beralasan}

Artinya argument yang diberikan selalu berdasarkan analisis dan mempunyai dasar kuat dari fakta fenomena nyata.

\section{Reflektif}

Artinya bahwa seorang pemikir kritis tidak menggunakan asumsi atau persepsi dalam berpikir atau mengambil keputusan

Berpikir adil dan Terbuka

Yaitu mencoba untuk brubah dari pemikiran yang salah dan kurang menguntungkan menjadi benar dan lebih baik.

Pemikir yang kritis akan memperhatikan apa yang penting dalam

sebuah situasi, mengeksplorasi mempertimbangkan

membayangkan dan semua alternatife, kode etik, dan kemudian membuat suatu keputusan. Cara untuk meningkatkan kemampuan berpikir kritis diantaranya pertama adalah membaca dengan kritis. Untuk berpikir secara kritis, seorang perawat harus bisa membaca dengan kritis pula dalam hal itu penting juga kita mengetahui bagaimana aplikasi berpikir kritis dalam keperawatan yaitu :

$\square$ Interpretasi $\square$ Analisis

Kesimpulan $\square$ Evaluasi

Penjelasan

Pengontrolan diri

Dalam berpikir kritis ini adalah salah satu komponen peting dalam pengambilan keputusan yang digunakan untuk mempertimbangkan pemecahan masalah yang akan diambil. Berpikir kritis merupakan proses kognitif level tinggi, karena termasuk dalam pengembangan kreativitas, pemecahan masalah dan pengambilan keputusan. Pengambilan keputusan dalam keperawatan diaplikasikan dengan cara membangun model dari beberapa disiplin ilmu yang antara lain adalah ekonomi, philosophy, politik, psikologi, teori operasional, administrasi bisnis, administrasi kesehatan, kebijakan kesehatan dan ilmu keperawatan. Model dibuat lebih spesifik dalam pemecahan masalah etika dan permasalahan klinis.

Untuk dapat melaksanakan pengambilan keputusan dengan baik, maka perlu adanya analisa kritis yang antara lain adalah menyusun pertanyaan-pertanyaan terkait

\section{PENUTUP}

Dalam memberikan asuhan keperawatan maupun tindakan keperawatan, perawat harus dituntut mampu dalam pengambilan keputusan dengan cara berpikir kritis dan kepercayaan diri mahasiswa keperawatan diantaranya adalah penentuan tujuan, membuat pertanyaan isu masalah yang ada, menetukan kerangka acuan, dimensi empiris, dimensi konsep, asumsi, implikasi 
dan konsekuensi, kesimpulan dan penutup.

Hal ini agar dapat perawat menjadi seorang pemikir yang kritis dalam melakukan asuhan keperawatan maupun tindakan keperawatan.

\section{KESIMPULAN}

Berpikir kritis merupakan kemampuan yang harus diasah oleh perawat maupun mahasiswa keperawatan karena dengan adanya bekal kemampuan berpikir kritis seorang perawat akan mempunyai keberanian untuk mengambil keputusan dan memikul tanggung jawab dari keputusan yang telah diambilnya. Pengambilan keputusan merupakan suatu pendekatan yang sistematis terhadap suatu hakikat suatu masalah dimana individu harus memiliki kemampuan berpikir kritis swngan mengandalkan pendidikan serta pengalaman yang efektif dalam pemecahan suatu masalah dan keputusan. Untuk mengabil suatu keputusan pun perawat tidak boleh asal- asalan harus memperhatikan banyak hal yang nantinya akan menjadi keputusan yang akurat dan jelas.

\section{SARAN}

Dalam berpikir kritis perawat perlu adanya penyusunan dan pelaksanaan program pelatihan berpikir kritis untuk perawat demi meningkatnya kualitas asuhan keperawatan dan dapat menentukan keputusan apa yang kelak akan diambil. 


\section{DAFTAR PUSTAKA}

Deswani. (2012). Proses Keperawatan dan Berfikir Kritis. Jakarta : Salemba Medika

Dini Sharfina. (2017). Hubungan Berpikir Kritis Perawat dalam Proses Pengambilan Keputusan Keperawatan. Jurnal Keperawatan, 4(2), 76-79.

DS, Bambang Sudono., A, Dhani Setya., \& H, Rif Atiningtyas. (2017). Gambaran Kemampuan Berpikir Kritis Perawat Primer dalam Pelaksanaan Asuhan Keperawatan di Rumah Sakit Islam Surakarta. Jurnal Ilmu Keperawatan Indonesia, 10(1), 79-106.

Indriate. (2013). Berfikir Kriris dalam Proses Keperawatan. Jurnal Keperawatan, 6(2), 89-93.

Kowiyah. (2012). Kemampuan Berpikir Kritis. Jurnal Pendidikan Dasar, 3(5), 175-179.

Nasution, S. (2016). Pengaruh Model Problem Based Learning Dan Kemampuan Berpikir Kritis Terhadap Kemampuan Pemecahan Masalah. Jurnal Pendidikan Fisika, 5(2), 112-117

Nur Fauziah Simamora. (2017). Proses Dan Model Pengambilan Keputusan Dalam Keperawatan Dengan Konsep Berfikir Kritis. Jurnal Keperawatan, 5(7), 157-160.

Bandiyah, Siti. (2017). Ketrampilan Dasar Keperawatan. Yogyakarta: Nuha Medika

Deniati, dkk. (2018). Pengaruh Berfikir Kritis Terhadap Kemampuan Perawat Pelaksana Dalam Melakukan Asuhan Keperawatan di Rumah Sakit Hermina Bekasi Tahun 2016. Jurnal Kesehatan Holistik, 12(1), 21-24

Haryanto, A. (2014). Hubungan Berfikir Kritis dan Waktu Tanggap Perawat dengan Kualitas Asuhan Keperawatan di Instalasi Gawat Darurat Rumah Sakit Islam Surabaya. Jurnal Sebelas Maret

Hastuti, W. (2017). Aplikasi Concept Mapping Dalam Pemberian Asuhan Keperawatan di Stase Maternitas. Jurnal Keperawaran dan Pemikiran Ilmiah. $3(3), 19-22$

Heni. (2017). Berfikir Kritis Dalam Proses Keperawatan. Jurnal Keperawatan, 3(1), 26- 29

Hutahaen, Serii. (2010). Konsep dan Dokumentasi Proses Keperawatan. Jakarta: Trans Info Media Jakarta 
Simamora, R. H. (2019). Menjadi perawat yang: CIH'HUY. Surakarta: Kekata Publisher.

Simamora, R. H. (2005). Hubungan Persepsi Perawat Pelaksana Terhadap Penerapan Fungsi Pengorganisasian Yang Dilakukan Oleh Kepala Ruangan Dengan Kinerjanya Diruang Rawat Inap RSUD Koja Jakarta Utara (Doctoral dissertation, Tesis FIK UI, Tidak dipublikasikan). 